Historic, archived document

Do not assume content reflects current scientific knowledge, policies, or practices. 



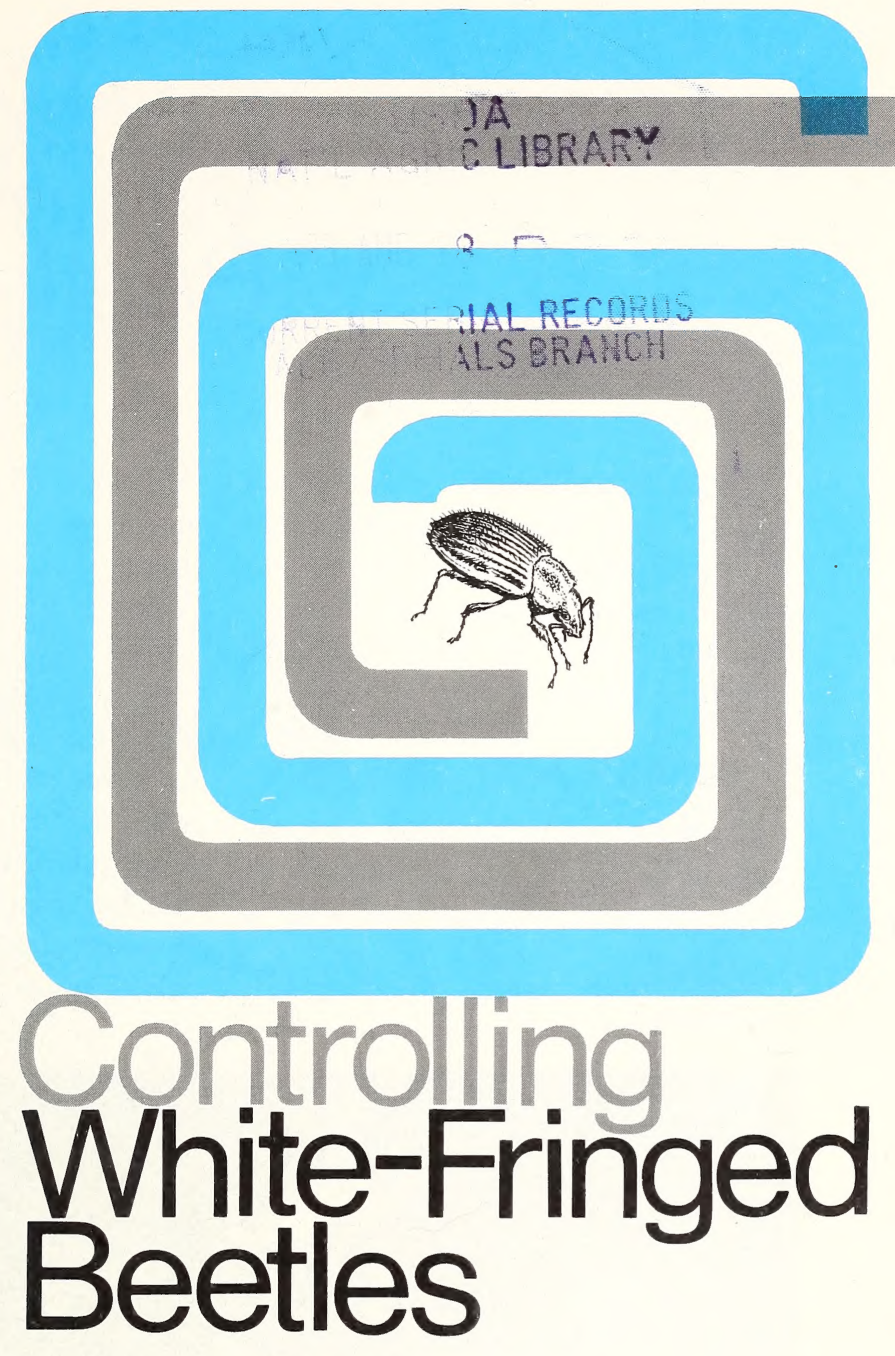




\section{Controlling White-Fringed Beetles}

White-fringed beetles ${ }^{1}$ can seriously damage your field and garden crops and ornamental plants unless you take proper control measures. Both larvae and adults feed on more than 300 species of plants.

\section{RANGE AND SPREAD}

White-fringed beetles occur in many parts of the Southeastern United States up to northern Virginia and west to

\footnotetext{
${ }_{1}$ Graphognathus spp.
}

Missouri. They could spread as far north as Pennsylvania to southern Iowa, and to irrigated areas of the Western States.

The eggs, larvae, and adults are easily spread in commerce. Eggs can be attached to plants, farm machinery, or other objects that come in contact with the soil, and in hay harvested from infested fields in late summer or fall. Larvae are transported in soil, sod, nursery stock, and root crops. The adults attach themselves to seed cotton,

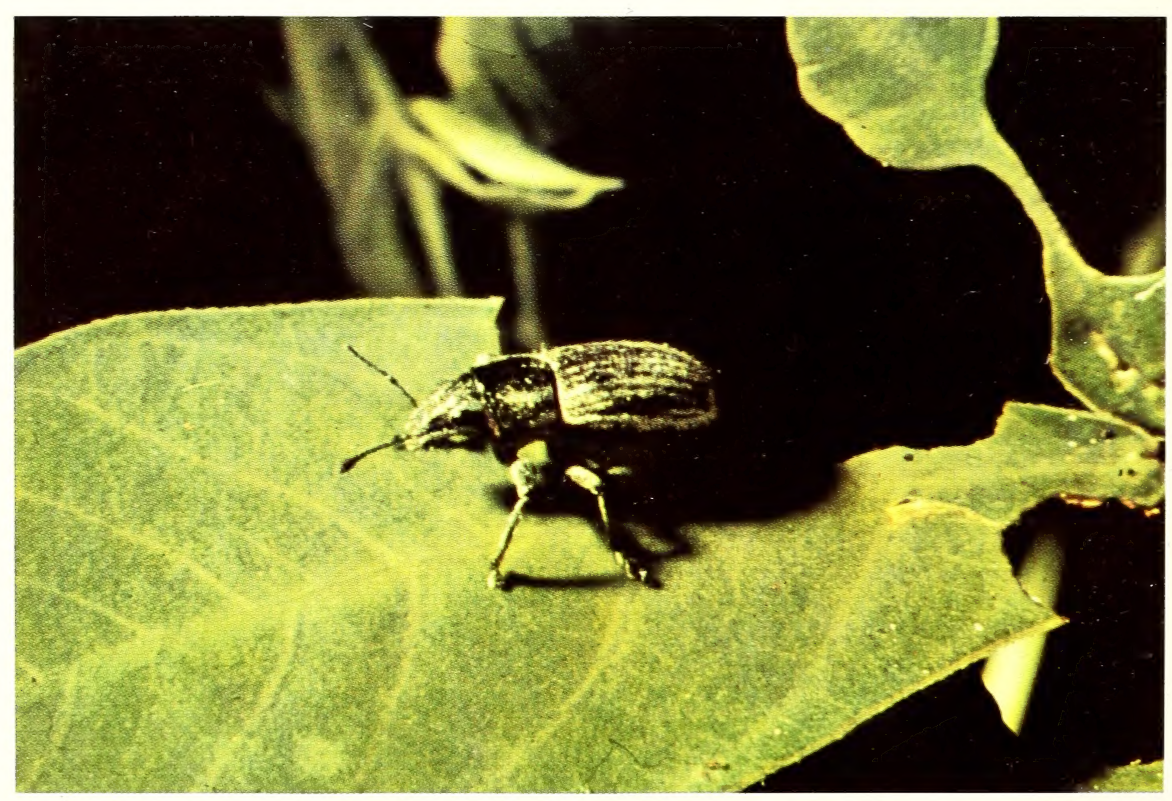

Feeding of adult white-fringed beetle. 
hay, farm machinery and tools, and even to people.

\section{DAMAGE}

The larvae, or grubs, live in the soil and feed on the roots of many kinds of plants. They rarely cause uniform damage over a large continuous area; sometimes, they completely destroy plants in one part of a field and leave plants elsewhere in the field practically untouched. Affected plants usually turn yellow, wilt, and die. Those that survive seldom develop normally. Adult beetles feed on foliage of broadleaf plants, but usually cause little damage.

Larvae prefer root crops and plants with taproots to plants with fibrous roots. They may completely sever the main root. They sometimes feed on roots of young peach, pecan, tung, and willow trees, and on parts of dead plants in the soil.

These beetles damage plants growing in well-drained, sandy loam more than those in heavy clay soils.

A very dry summer can slow down development of the beetles. A heavy, week-long rain can kill many small larvae.

\section{DEVELOPMENT}

One generation of white-fringed beetles develops each year. Larvae spend about 9 months in the soil.

Soon after hatching, larvae enter the soil and feed on roots. They are legless, cream colored, and, when full grown, are about 1/2 inch long. Fullgrown larvae build cells in the soil where they transform into pupae. In about 2 weeks they develop into adults.

Adults begin emerging from the ground in early May and continue until early fall, depending on the area and the amount of moisture in the soil. Adult beetles are dark gray, are about $7 / 16$ inch long, and have a white fringe, or band, around the outer edge of their body.

All the adults are egg-laying females. They live for 2 to 5 months and lay eggs during most of that time. Eggs are laid in masses of 11 to 14 in the soil near roots or where soil is touching sticks, gravel, stems, or other objects lying on the ground or sticking out of the soil. A sticky substance coats the eggs and makes them adhere to one another and to roots or other objects. Beetles that feed on peanuts, cocklebur, ragweed, soybeans, and strawberries lay a great many eggs; those that feed on cowpeas, lespedeza, blackberries, and tobacco lay few eggs.

Eggs hatch in about 17 days in warm weather but take longer to hatch in cool weather. A few eggs overwinter and hatch in the spring, but most of the insects overwinter in the soil as larvae.

\section{CULTURAL CONTROL}

To help control white-fringed beetles, rotate peanuts, soybeans, and velvetbeans-crops that encourage an increase in the numbers of beetles-with crops that are not favorable to such an increase: pasture grasses, small grains, and corn. Plant corn in solid stands; do not interplant with a legume.

Do not grow susceptible crops in the same field more often than once every 3 or 4 years.

Add organic matter to the soil. An economical method is to plow under a winter cover crop. This will help reduce larval damage. 


\section{CHEMICAL CONTROL}

\section{Cropland}

You can control white-fringed beetles by applying chlordane to soil planted with certain crops. The insecticide label contains information about the specific crops on which chlordane has been registered for use. The label also specifies the recommended dosage for control of the white-fringed beetle. Chlordane may be applied as a spray prepared from an emulsifiable concentrate or wettable powder, or as granules, ready for immediate application.

The most effective method of applying chlordane is to spread the insecticide evenly over the surface of the soil prior to planting, using properly calibrated hand or power ground equipment or an airplane. Granular formulations are preferred when appli- cations are made by airplane. The insecticide should be mixed into the top 3 inches of soil immediately after application. If there is a heavy growth of vegetation on the field, this vegetation should be plowed under before applying the insecticide.

If you are growing cotton on the land, you can apply chlordane in the drill row at planting time at the rate of 1 to 2 pounds active ingredient per acre.

If the distance between drill rows is more than 6 feet, then apply minimum dosage per acre; if it is less than $3 \frac{1}{2}$ feet, apply maximum dosage per acre. You can apply the insecticide by itself or combine it with fertilizer. This method does not give as good control as the soil surface application.

Chlordane applied to the soil will give control for 3 years. Row treatment

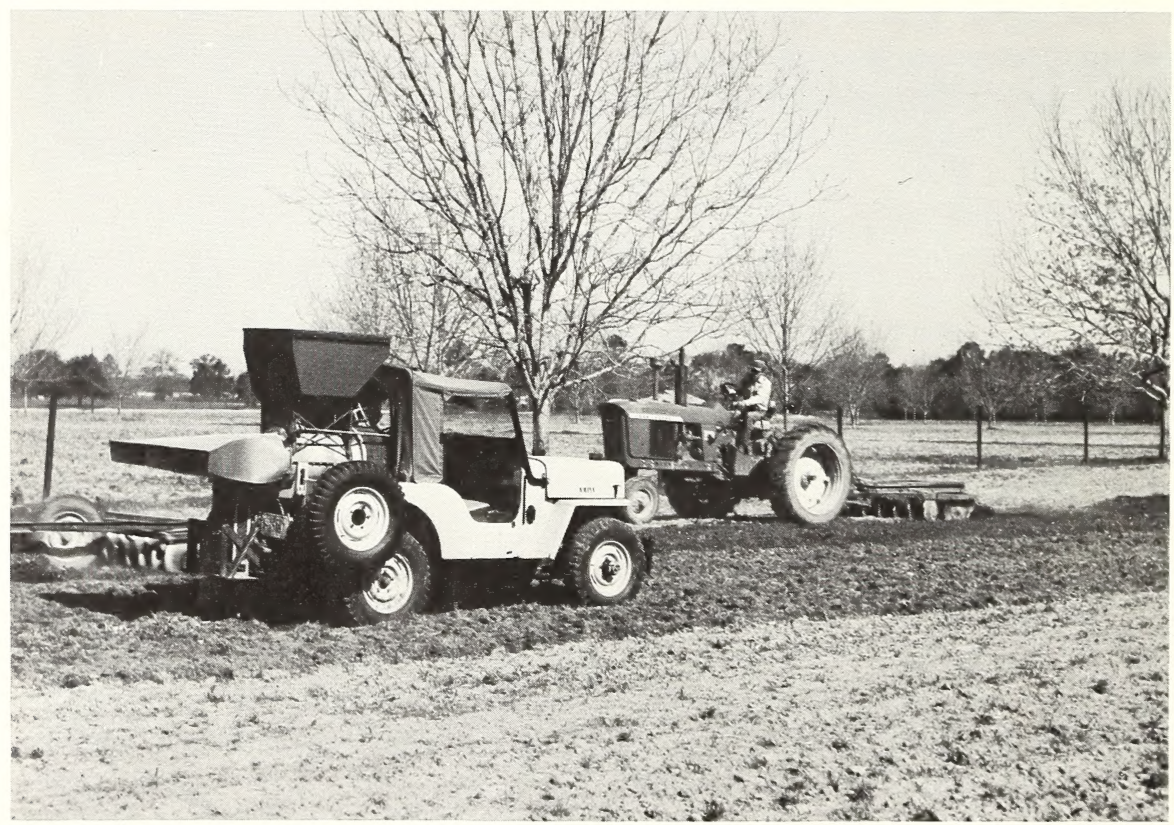

Applying granular insecticide to soil. 


\section{WHITE-FRINGED BEETLE}

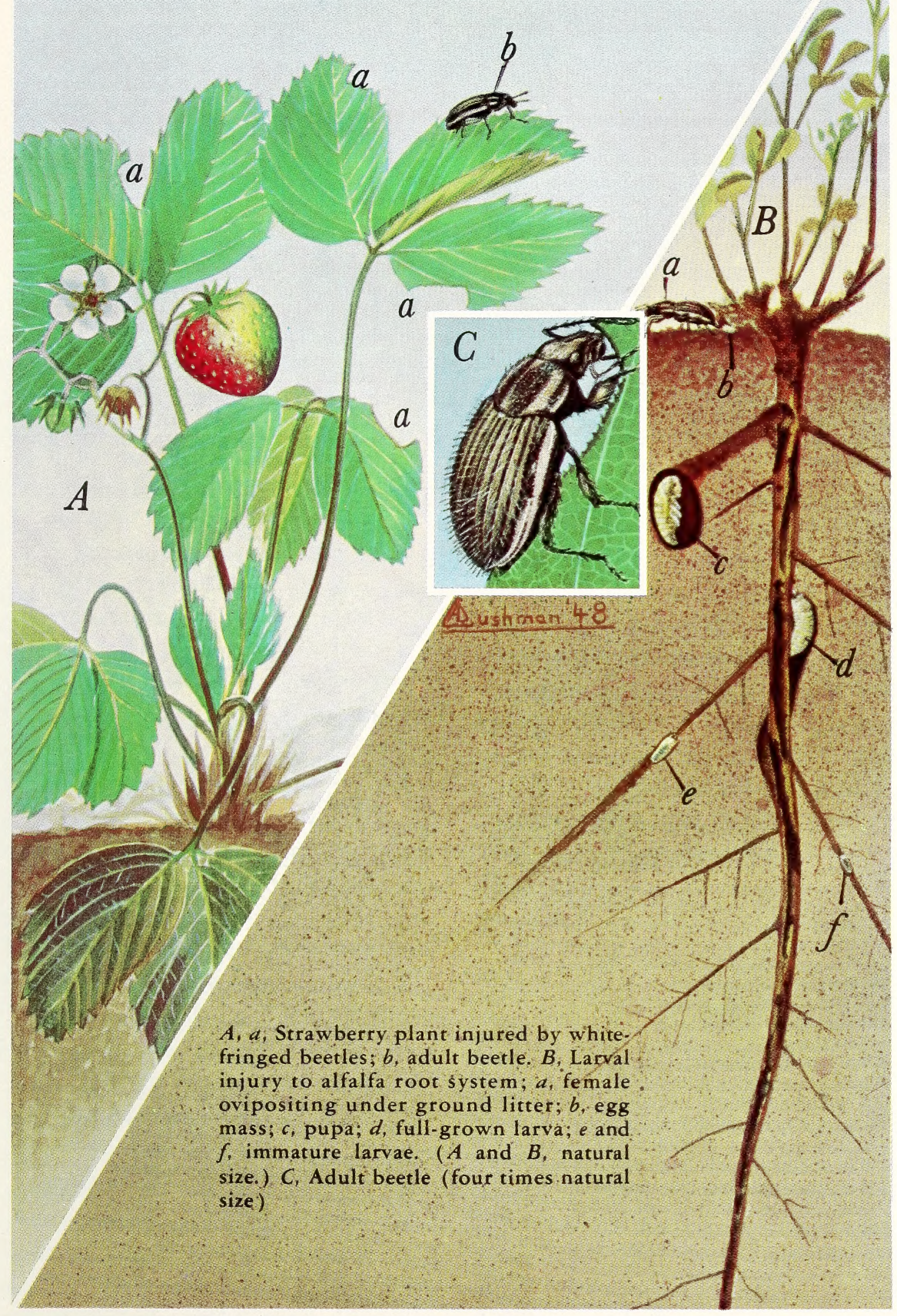


of cotton controls the beetles for 1 year.

Certain chemical insecticides have been used in the past to control whitefringed beetles on cropland. However, many States have adopted or are considering restrictive legislation affecting the use of these insecticides. For current information about insecticides approved for control of white-fringed beetles in your State, consult your local agricultural agent or State agricultural experiment station.

\section{Nonagricultural Land}

Federal or State quarantine programs may require you to control white-fringed beetles on nonagricultural land. These include fields not used for growing crops or grazing, for nurseries, storage areas, railroad yards, sidings, and roadways. Treatments are applied under the supervision of Federal and State plant protection workers. Consult them for additional information about insecticides currently approved for these treatments, proper rates of application, and other details.

\section{FINDING AND REPORTING INFESTATIONS}

You can help prevent the spread of white-fringed beetles by finding and reporting infestations.

\section{Finding Larvae}

- Look around roots, particularly if plants are wilting or dying.

- Look for wilting, reddening, and yellowing of young plants in fields, vegetable gardens, and flower beds. Examine the soil where there are skips in rows of plants.

- Dig up abnormal plants and look

\section{Quarantines}

To prevent the spread of whitefringed beetles, Federal and State quarantines have been established. These quarantines are designed to control the movement of articles that could carry the pests.

In quarantined areas, plants with roots attached, certain crops, equipment, soil, forest products, and other articles must be certified by a plant protection inspector before they can be shipped to uninfested areas. To be eligible for certification, the articles must be treated or found to be free of white-fringed beetles.

For further information about State and Federal quarantine regulations contact your State department of agriculture, county agricultural agent, or a plant protection office of the U.S. Department of Agriculture.

for larvae in the soil and on the roots. Examine several plants that are wilting or yellowing.

\section{Finding Adult Beetles}

- Look for sawtooth cuts on outer edges of leaves; adults do not eat holes in the leaves. (See photo, p. 2.)

- Look for damage on leaves of crops such as soybeans, velvetbeans, peanuts, cotton, and clover.

- Look for adults on broadleaf weeds in fields, terraces, turnrows, and fence lines. If weeds and small grains are growing in the same field, beetles will feed on the weeds. 


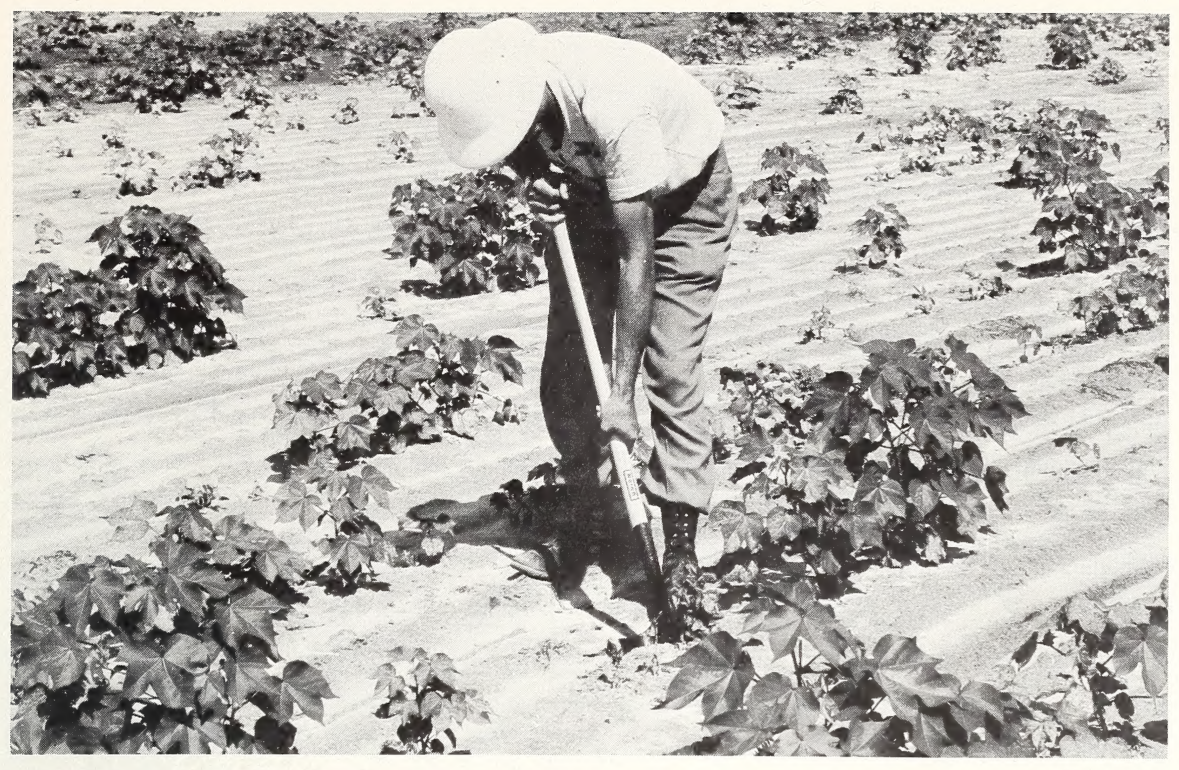

$\mathrm{BN}-23080$

Looking for larvae in soil in cottonfield infested with white-fringed beetles.

- If you do not find adults on leaves, inspect the base of the plants and look under leaves and in the grass nearby.

\section{Reporting}

If you find adult beetles or larvae that resemble the one in the color drawing, place several in a small bottle of rubbing alcohol and send the bottle to your local agricultural agent, the nearest plant protection inspector, your State department of agriculture, or your State entomologist.

When sending specimens, include your name and address and tell where and when the insects were found. Do not send live insects through the mail.

\section{PRECAUTIONS}

Pesticides used improperly can be injurious to man, animals, and plants. Follow the directions and heed all precautions on the labels.
Store pesticides in original containers under lock and key-out of the reach of children and animals-and away from food and feed.

Apply pesticides so that they do not endanger humans, livestock, crops, beneficial insects, fish, and wildlife. Do not apply pesticides when there is danger of drift, when honey bees or other pollinating insects are visiting plants, or in ways that may contaminate water or leave illegal residues.

Do not feed potatoes, turnips, peanut forage, hulls, or silage made from plants from fields treated with chlordane to dairy animals or to animals being finished for slaughter. Do not allow grazing on fields treated with chlordane.

Avoid prolonged inhalation of pesticide sprays or dusts; wear protective clothing and equipment if specified on the container.

If your hands become contaminated 
with a pesticide, do not eat or drink until you have washed. In case a pesticide is swallowed or gets in the eyes, follow the first aid treatment given on the label, and get prompt medical attention. If a pesticide is spilled on your skin or clothing, remove clothing immediately and wash skin thoroughly.

Chlordane can be absorbed directly through the skin in harmful quantities. When working with this insecticide in any form, take extra care not to let it come into contact with the skin.

Do not clean spray equipment or dump excess spray material near ponds, streams, or wells. Because it is difficult to remove all traces of herbicides from equipment, do not use the same equipment for insecticides or fungicides that you use for herbicides.

Dispose of empty pesticide containers promptly. Have them buried at a sanitary land-fill dump, or crush and bury them in a level, isolated place.

Note: Some States have restrictions on the use of certain pesticides. Before applying insecticides, check your State and local regulations.

The white-fringed beetle is easy to mistake for other insects. The color illustrations will help you distinguish it from similarlooking beetles.

\author{
Prepared by \\ Entomology Research Division, \\ Agricultural Research Service \\ Plant Protection and Quarantine Programs, \\ Animal and Plant Health Service,
}

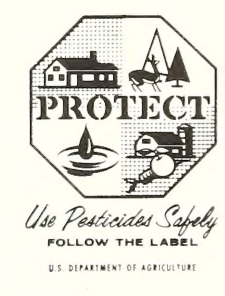

This edition replaces all previous editions of this publication. Because of changed insecticide recommendations, earlier copies should be destroyed.

Washington, D.C.

Revised April 1972

For sale by the Superintendent of Documents, U. S. Government Printing Office

Washington, D.C. 20402 - Price 20 cents

Stock Number 0100-1503 

